\title{
Working Capital Management (WCM) and Performance of SMEs: Evidence from India
}

\author{
David K. Chalmers \\ School of Strategy and Business \\ UT Toronto - Canada \\ Luca Sensini \\ Department of Management and Innovation System \\ University of Salerno - Italy \\ Amit Shan \\ BeLab, NIBS \\ New Delhi - India
}

\begin{abstract}
This study analyzes the relationship between working capital and company performance, deepening this relationship for each of the elements that make up working capital. The SMEs analyzed are those present in the IPO index of the Bombay Stock Exchange (BSE) for a total period of six years, from 2012 to 2017 included. Two criteria were used to select companies to be analyzed. Firstly, the companies had to have all the information needed for this study during the reporting period. Secondly, the companies were not part of a group. Based on these criteria, 42 SMEs were analyzed. The analysis highlighted a negative and significant relationship between net working capital (NWC), accounts receivables (AR), and profitability. Conversely, accounts payables (AP) and inventory (INV) are positively related to profitability. The robustness checks confirmed the validity of our outcomes. The results of this study enrich the existing literature, providing further empirical evidence related to the specific context analyzed. In addition, the results can be helpful for Indian SME owners and managers to guide financial decisions on working capital management.
\end{abstract}

Keywords: Working Capital Management, Performance, Inventory, Liquidity, SMEs

\section{Introduction}

Decisions affecting working capital management are crucial for companies of all sizes, as they have a significant impact on liquidity. After the seminal paper of Smith (1980), which highlighted the influence of working capital management on the profitability and risk level of companies, numerous contributions have been developed on the topic, focusing attention on large companies and SMEs in different economic contexts (Khoury et al., 1999; Deloof 2003; Howorth and Westhead, 2003; Filbeck and Krueger, 2005; Raheman and Nasr, 2007; Baños-Caballero et al., 2012; Chen et al., 2014; Aktas et al., 2015; among others). However, as highlighted by the literature (Whited, 1992), the operating context in which large companies and SMEs decide on working capital management policies is substantially different (Chen et al., 2014). In this perspective, financial constraints often influence the working capital management of SMEs, leading to decisions dictated by the above constraints rather than correct financial management choices (Stiglitz\& Weiss A., 1981; Nayak and Greenfield, 1994; Peel et al., 2000). The literature that has focused attention on the relationship between working capital and profitability has shown conflicting results, suggesting in some contexts a positive relationship and in other contexts a negative relationship.

Given the importance that working capital has for the management of SMEs, this study intends to investigate first of all the relationship between working capital and profitability. Furthermore, considering that the management policies of every single element of working capital (Accounts Receivables, Accounts Payables, and Inventory) can influence profitability, this study intends to investigate the relationship between each element of working capital and profitability. The SMEs analyzed are those present in the IPO index of the Bombay Stock Exchange (BSE). The financial information was collected for the period from 2012 to 2017. The companies to be included in the analysis were selected based on two criteria. First, the companies had to have all the necessary information for this study available during the reporting period. Second, companies were not part of a group. Based on the criteria just mentioned, 42 SMEs were analyzed.

The analysis highlighted a negative and significant relationship between Net Working Capital (NWC), Accounts Receivables (AR) and profitability, and a positive relationship between Accounts Payables (AP), Inventory (INV) and profitability. 
The study contributes to the existing literature on this issue, highlighting the relationship between working capital and profitability of a specific type of Indian SME. Furthermore, this paper also focuses attention on the relationship between each element of working capital and profitability, providing further empirical evidence on this research topic. Finally, the results of this study may be helpful to Indian SME owners and managers to guide financial decisions regarding working capital management.

The paper is organized as follows. The next section presents the literature review and research hypotheses. Section 3 the research methodology. Finally, section 4 highlights the results of this study, while the latter section reports the concluding remarks.

\section{Literature Review and Research Hypotheses}

Working capital management covers all decisions that have an impact on current assets and liabilities and consequently on corporate liquidity (Sensini, 2020). Traditionally, financial literature has always focused on medium-long term decisions, paying less attention to short-term ones. However, starting from the seminal paper of Smith (1980), which highlighted that the management of working capital has a fundamental influence on the profitability and on the level of risk of companies, numerous contributions have been developed which have reassessed the importance of the decisions of short term for the survival and development of companies (Khoury et al., 1999; Baños-Caballero et al., 2012; Chen et al., 2014; Aktas et al., 2015; among others).

Initially, the relationship between WCM and profitability was investigated focusing mainly on large companies (Deloof 2003; Filbeck and Krueger, 2005; Raheman and Nasr, 2007). However, in recent years, this theme was also investigated with reference to small and medium-sized enterprises in different economic contexts (Howorth and Westhead, 2003; P.Garcia-Teruel and Martinez-Solano, 2007; Afrifa, 2013; among others). The literature has suggested several models for the management of working capital: aggressive, conservative, and moderate (Afza\&Nazir, 2009; Ukaegbu, 2014). Each of these models involves a different approach to working capital management and presupposes the search for a trade-off between risk and profitability. However, the optimal trade-off depends on multiple environmental conditions, on the market, and on the specific characteristics of the companies. Each of these factors can affect the way working capital is managed (Chen et al., 2014). In this perspective, the relationship between WCM and profitability also depends on the size of the company, its life cycle, the power relationship with the stakeholders. In particular, larger firms have greater bargaining strength and easier access to financial resources than SMEs (Whited, 1992). This circumstance, although not sufficient if not supported by proper financial management, facilitates the management of working capital in large companies. On the other hand, the financial constraints that often characterize SMEs influence the management of working capital and sometimes leading to decisions dictated by the above constraints rather than correct financial management choices (Chen et al., 2014).

The literature has widely highlighted the origin of these constraints, attributing them to information asymmetry problems (Stiglitz\& Weiss A., 1981), to transaction costs, to the lack of transparency of the accounting documentation (Sensini, 2003), to excessive short-term debt (Peel et al., 2000), to the volatility of the results, to the lack of adequate collaterals (Nayak and Greenfield, 1994; Khoury et al., 1999).

Given these constraints, the management of working capital is relevant in SMEs, as it can significantly influence the prospects for survival and development.

In the context outlined, the literature that has focused attention on working capital management policies has shown conflicting results. In summary, studies have highlighted two different points of view.

On the one hand, some researchers have reported that increasing investment in working capital has a positive impact on profitability. In this perspective, these studies have suggested that the growth in working capital may lead to an increase in sales, an improvement in relations with customers, a reduction in supply costs, a reduction in information asymmetry, thus leading to an increase in profitability (Smith, 1987; Emery, 1987; Brennan et al., 1988; Blinder and Maccini, 1991; Fazzari and Petersen, 1993; Lee and Stowe, 1993; Wilner, 2000; Wang, 2002; Deloof, 2003; Lazaridis and Tryfonidis, 2006; García-Teruel and Martínez-Solano, 2007; Ramachandran and Janakiraman, 2009; Zariyawati et al., 2009; Erasmus, 2010; Aktas et al., 2015; among others). On the other hand, several researchers have suggested that the increase in working capital has a negative impact on profitability. In this perspective, these studies have highlighted that the investment in working capital causes the need for additional financing, the increase in financial costs, an increase in storage costs, causing a negative impact on profitability (Kim \& Chung, 1990; Ek and Guerin, 2011; Alipour, 2011; Karaduman et al., 2011; among others) and an increase in financial distress and the probability of bankruptcy (Kieschnick et al., 2013). 
The results of the literature are conflicting and therefore do not provide univocal indications to the owners and managers of SMEs.

\section{Therefore, we formulate the following research hypotheses:}

H1a: There is a positive relationship between working capital and profitability. $\mathrm{H} 1 \mathrm{~b}$ : There is a negative relationship between working capital and profitability.

Given the importance that working capital has for the management of SMEs, this study intends to further investigate the topic, also analyzing the relationship between every single element of working capital (Accounts Receivables, Accounts Payables, Inventory) and the profitability.

The relationship between each element of the working capital and profitability depends on the management policy used by the company (Nazir and Afza, 2009). In this regard, some studies (Reason, 2002) have suggested that the aggressive management of all elements of working capital favors the formation of significant cash flows and limits the possibility of financial difficulties (Chen et al. 2014). In this perspective, the decrease in AR has a positive impact on profitability (Bhattacharya, 2008). Therefore, in consideration of the above, our research hypothesis is as follows:

\section{H2: There is a negative relationship between $A R$ and profitability.}

With reference to AP, the literature has shown conflicting results. Some authors have suggested that by shifting the payment of debts over time and therefore increasing the delays obtained by suppliers, a positive impact on profitability is determined (Bhattacharya, 2008; Sharma and Kumar, 2011). Conversely, other authors have highlighted a negative relationship between debt and profitability, underlining that the increase in delays can lead to the deterioration of relations with suppliers and the loss of cash discounts (Laziridis and Tryfonidis, 2006; Samiloglu and Demrigunes, 2008; Chen et al., 2014).

\section{Therefore, based on what has just been highlighted, we formulate the following research hypotheses:}

H3a: There is a positive relationship between AP and profitability;

$\mathrm{H} 3 \mathrm{~b}$ : There is a negative relationship between AP and profitability.

Inventory management (INV) is significantly influenced by the policy used by firms. In this perspective, an aggressive strategy allows to reduce storage costs and to reduce supply costs, determining a positive effect on profitability (Laziridis and Tryfonidis, 2006; Nazir and Afza, 2009). In this perspective, some authors have suggested a negative relationship between inventory and profitability (Chen et al., 2005; Baños-Caballero et al., 2010)

Conversely, other authors have highlighted that a more conservative approach to inventory management has a positive effect on profitability (Blinder and Maccini, 1991; Bhattacharya, 2008) although it increases costs and increases the credit risk (Aktas et al., 2015).

\section{Therefore, based on what has just been highlighted, we formulate the following research hypotheses:}

H4a: There is a positive relationship between INV and profitability;

H4b: There is a negative relationship between INV and profitability.

\section{Methodology Research}

In line with our research hypotheses, to study the relationships between working capital and profitability we followed the following quantitative approach:

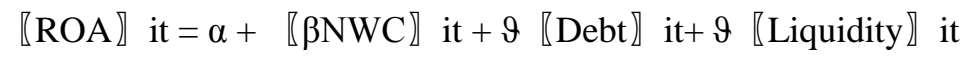

Furthermore, to study the relationship between each component of working capital and profitability, we followed the following quantitative approach:

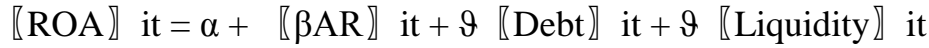

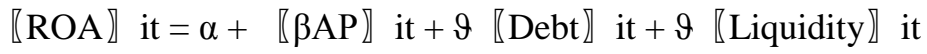

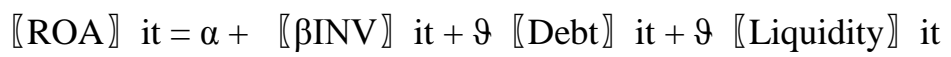

Finally, to strengthen the predictive capacity of the model, we used debt and liquidity as control variables.

All the variables used and the calculation methods are specified in table 1. 
Tab. 1 - Variables

\begin{tabular}{ll}
\hline $\begin{array}{l}\text { Dependent Variables } \\
\text { ROA }\end{array}$ & EBIT/Total Assets \\
\hline $\begin{array}{l}\text { Independent Variables } \\
\text { NWC }\end{array}$ & NWC, Conversion cycle of net working capital; the difference between the time it takes to convert a current \\
& asset into liquidity and the time it takes to convert debt into a liquidity exit \\
AR & Accounts Receivable, the average number of days to collect a credit \\
AP & Account Payables, the average number of days to pay off debts \\
INV & Inventories, the average number of day that firms hold their inventory \\
\hline Control Variables & Debt/Total Assets \\
Debt & Current Assets/Current Liabilities \\
Liquidity &
\end{tabular}

The companies studied are the firms present in the SME IPO index at the Bombay Stock Exchange (BSE). Financial information was collected for the period from 2012 to 2017 from the database of the Center for Monitoring Indian Economy (CMIE). Two criteria were used to select the firms.

Firstly, the companies had to have all the information needed for this study available throughout the period under analysis. Secondly, companies were not part of a group. Based on the criteria just mentioned, 42 SMEs were analyzed.

\section{Research Results and Discussion}

Table 2 shows the descriptive statistics for each of the variables used in the analysis.

Within the limits of the explanatory skills of this type of analysis, inventories and accounts payables are characterized by a normal distribution with an asymmetry close to zero. On the other hand, net working capital, accounts receivables, and liquidity are not normally distributed, as they present anomalous values.

Tab. 2 - Descriptive Statistics

\begin{tabular}{llllll}
\hline Variable & Mean & Median & StDev & Skewness & Kurtosis \\
\hline ROA & 3.79 & 2.48 & 8.31 & 3.34 & 15.7 \\
NWC & 316.08 & 56.91 & 2012.42 & 6.59 & 53.27 \\
AR & 96.5 & 37.3 & 166.86 & 4.11 & 32.76 \\
AP & 59.81 & 27.9 & 131.47 & 4.89 & 38.56 \\
INV & 32.26 & 26.85 & 23.12 & 0.69 & 2.83 \\
Debt & 0.43 & 0.44 & 0.23 & 0.36 & 1.89 \\
Liquidity & 4.1 & 1.74 & 9.14 & 5.11 & 31.63 \\
\hline
\end{tabular}

Table 3 shows the correlation analysis and significance level. Reviewing the data shows that net working capital (NWC) and AR are negatively correlated with profitability, while AP and liquidity show a significant correlation.

Tab. 3 - Correlation Matrix

\begin{tabular}{llllllll}
\hline & I & II & III & IV & V & VI & VII \\
\hline ROA & 1 & & & & & & \\
NWC & $-0.12^{* *}$ & 1 & & & & & \\
AR & $-0.11^{* *}$ & -0.01 & 1 & & & & \\
AP & -0.06 & 0.01 & $0.044^{* *}$ & 1 & & & \\
INV & 0.112 & $-0.17^{* *}$ & $-0.14^{* *}$ & -0.13 & 1 & & \\
Debt & -0.07 & 0.01 & 0.06 & -0.02 & -0.01 & 1 & \\
Liquidity & 0.019 & -0.05 & $-0.13 * * *$ & 0.01 & 0.02 & -0.05 & 1 \\
\hline
\end{tabular}

Significance levels: $*<0.05 ; * * \mathrm{p}<0.01 ; * * * \mathrm{p}<0.001$.

Table 4 highlights the development of the quantitative analysis deriving from the application of equation 1 for the study of the relationship between working capital and profitability and equations 2, 3 and 4 for the study of the relationship between each component of the working capital (AR, AP, INV) and the profitability. 
Tab. 4 - Relationship between WCM and Firm Performance

\begin{tabular}{lllll}
\hline & 1 & 2 & 3 & 4 \\
\hline NWC & $-0.027^{* *}$ & & & \\
AR & & $-0.004^{* * *}$ & $0.005^{* * *}$ & \\
AP & & & & $0.009 * * *$ \\
INV & -0.618 & -0.687 & $-2.114^{* * *}$ & -0.648 \\
Debt & -0.001 & 0.017 & $0.458^{* * *}$ & 0.053 \\
Liquidity &
\end{tabular}

The analysis shows a negative and significant relationship between NWC and AR and profitability. Therefore, hypotheses $\mathrm{H} 1 \mathrm{~b}$ and $\mathrm{H} 2$ must be accepted, while hypothesis H1a must be rejected.

The results relating to AR show that the reduction of the collection time for the credits increases the profitability, in accordance with what is suggested by the literature examined. The analysis highlights a positive relationship between debt (AP) and profitability, therefore hypothesis H3a must be accepted, while hypothesis H3b must be rejected. This result is in line with other research (Bhattacharya, 2008; Sharma and Kumar, 2011) which suggests a positive impact of the increase in delays to suppliers.

Finally, the analysis highlights a positive relationship between inventory and profitability. Consequently, the H4a hypothesis must be accepted, while the H4b hypothesis must be rejected. Therefore, managing a larger inventory, while involving higher storage and financing costs, reduces the risks associated with a more aggressive inventory policy and has a positive impact on profitability.

To test the solidity of the model, we performed the analyzes shown in table 5, which confirm the validity of the results.

Tab. 5 - Robustness Checks

\begin{tabular}{lllll}
\hline & NWC & AR & AP & INV \\
\hline Wald Chi2 & $27.81^{* * *}$ & $30.26^{* * *}$ & $35.04 * * *$ & $29.85^{* * *}$ \\
White's Test & $94.16^{* * *}$ & $81.46^{* * *}$ & $73.07^{* * *}$ & $68.35^{* * * *}$ \\
\hline
\end{tabular}

\section{Concluding Remarks}

Given the importance that circulating capital has for the management of SMEs, this study examined the relationship between circulating capital and profitability. Furthermore, considering that the management policies of every single element of working capital (Receivables, Payables, and Inventory) can influence profitability, this study has deepened the relationship between each element of working capital and profitability.

The SMEs analyzed are those present in the IPO index of the Bombay Stock Exchange (BSE) for a total period of six years, from 2012 to 2017 included. The companies to be included in the analysis were selected based on two criteria. Firstly, the companies had to have all the information needed for this study throughout the reporting period. Secondly, the companies were not part of a group. On the basis of the criteria just mentioned, 42 SMEs were analyzed.

The analysis highlighted a negative and significant relationship between Net Working Capital (NWC), Accounts Receivables (AR), and profitability. Conversely, Accounts Payables (AP), and Inventory (INV) are positively correlated with profitability. The robustness checks confirmed the validity of our results.

The results of this study have several theoretical and practical implications. Firstly, these results highlight the results of a specific category of Indian SMEs, present in the IPO index of the Bombay Stock Exchange (BSE). In addition, the results also highlight the specific relationship between the individual components of working capital and profitability.

In this perspective, the results of this study enrich the existing literature, providing further empirical evidence referring to the specific context analyzed.

Finally, the results of this study may be helpful to Indian SME owners and managers to guide financial decisions on working capital management.

\section{Authorship contribution Statement}

Chalmers D.K and Sensini L.: Conceptualization, Methodology, Data analysis, Validation; Shan A.: Data curation, Data analysis. 


\section{References}

Afrifa, G.A. (2013). Working Capital Management Practices of SMEs: The Role of Education and Experience, International Journal of Academic Research in Accounting, Finance and Management Sciences 3 (4): 185-196.

Afza, T., Nazir, M. S. (2009). Impact of Aggressive Working Capital Management Policy on Firms' Profitability, The IUP Journal of Applied Finance, 15(8), 19-30.

Aktas, N., Croci, E., Petmezas, D. (2015). Is working capital management value-enhancing? Evidence from firm performance and investments, Journal of Corporate Finance, 30, 98-113.

Alipour, M. (2011), Working capital management and corporate profitability: Evidence from Iran. World Applied Sciences Journal, 12(7), 1093-1099.

Baños-Caballero, S, Garcìa-Teruel, P.J., Martınez-Solano, P. (2012). How does working capital management affect the profitability of Spanish SMEs? Small Business Economics (39), 517-529.

Bhattacharya H., Theory of trade credit: limitations and applications, http://ssrn.com/abstract=1286443.

Blinder, A.S. and Maccini, L.J. (1991), The resurgence of inventory research: what have we learned?, Journal of Economic Surveys, Vol. 5 No. 4, pp. 291-328.

Brennan, M.J., Maksimovics, V. and Zechner, J. (1988), Vendor financing, Journal of Finance, Vol. 43 No. 5 , pp. 1127-1141.

Chen, H., Frank M., Z., Wu, Q. W. (2005), What actually happened to the inventories of American companies between 1981 and 2000? Management Science, 51(7), 1015-1031.

Chen, J., Sensini, L. (2014). Net working capital, Cash flow and Performance of SMEs: an exploratory study. Small and Medium Size Enterprises: Governance, Management and Performance, 296-315, Malta Univ. Press.

Chen, J., Hughes, C., Sensini, L. (2014), Credit risk measurement of SMEs, International Conference on Economics, Finance and Risk, 139-163.

Deloof, M. (2003), Does working capital management affect profitability of Belgian firms? Journal of Business Finance \& Accounting, 30 (4), pp. 573-587.

Ek, R. and Guerin, S. (2011), Is there a right level of working capital?, Journal of Corporate Treasury Management, Vol. 4 No. 2, pp. 137-149.

Emery, G.W. (1987), An optimal financial response to variable demand, Journal of Financial and Quantitative Analysis, Vol. 22 No. 2, pp. 209-225.

Erasmus, P.D. (2010), Working capital management and profitability: the relationship between the net trade cycle and return on assets", Management Dynamics, Vol. 19 No. 1, pp. 2-10.

Fazzari, S.M. and Petersen, B. (1993), Working capital and fixed investment: new evidence on financing constraints, The Rand Journal of Economics, Vol. 24 No. 3, pp. 328-342.

Filbeck, G., Krueger, T. (2005). Industry Related Differences in Working Capital Management, Journal of Business, Vol. 20 (2), 11-18.

Garcia-Teruel, P.J., Martinez-Solano, P. (2007). Effects of Working Capital Management on SME Performance, International Journal of Managerial Finance 3 (2), 164-177.

Howorth C., Westhead, P. (2003). The focus of working capital management in UK small firms, Management Accounting Research, 14 (2), 94-111.

Karaduman, H. A., Akbas, H. E., Caliskan, A. O., \& Durer, S. (2011), The relationship between working capital management and profitability: Evidence from an emerging market. International Research Journal of Finance and Economics, 62(6), 61-67.

Khoury, N.T., Smith, K.V., MacKay, P.I. (1999). Comparing working capital management practices in Canada, the United States and Australia: a note, Canadian Journal of Administrative Sciences, 16 (1), 53-57.

Kim, Y.H. and Chung, K.H. (1990), An integrated evaluation of investment in inventory and credit: a cash flow approach, Journal of Business Finance and Accounting, Vol. 17 No. 3, pp. 381-389.

Kieschnick, R., Laplante, M. and Moussawi, R. (2013), Working capital management and shareholders' wealth, Review of Finance, Vol. 17 No. 5, pp. 1827-1852.

Lazaridis, I. and Tryfonidis, D. (2006), Relationship between working capital management and profitability of listed companies in the Athens stock exchange, Journal of Financial Management and Analysis, Vol. 19 No. 1, pp. 26-35.

Lee, Y.W. and Stowe, J.D. (1993), Product risk, asymmetric information, and trade credit, Journal of Financial and Quantitative Analysis, Vol. 28 No. 2, pp. 285-300.

Nayak, A., Greenfield, S. (1994). The use of management accounting information for managing micro businesses. In: Hughes, A., Storey, D.J. (Eds.), Finance and The Small Firm. Routledge, London. 
Nazir, M. S., \&Afza, T. (2009), Working capital requirements and the determining factors in Pakistan. IUP Journal of Applied Finance, 15(4), 28-38

Peel, M.J., Wilson, N., Howorth, C.A. (2000). Late payment and credit management in the small firm sector: some empirical evidence, International Small Business Journal, 18 (2), 17-37.

Raheman, A., Nasr, M. (2007). Working Capital Management and Profitability - Case of Pakistani Firms, International Review of Business Research Papers, Vol.3(1), 279-300.

Ramachandran, A. and Janakiraman, M. (2009), "The relationship between working capital management efficiency and EBIT”, Managing Global Transitions, Vol. 7 No. 1, pp. 61-74.

Reason, T. (2002), The working capital survey, CFO Magazine (2002), pp. 2-15

Samiloglu, F., Demirgunes, K. (2008), The effect of working capital management on firm profitability: Evidence from Turkey. The International Journal of Applied Economics and Finance, 2(1), 44-50.

Sensini L. (2020), Working capital management and performance: evidence from Italian SME's, International Journal of Business Management and Economic Research (IJBMER), Vol 11(2),2020, 1749-1755.

Sensini L. (2003), L'analisi economico-finanziaria nel governo della piccola impresa, Aracne, Roma.

Sharma, A. K., Kumar, S. (2011), The effect or working capital management of the firm's profitability: Empirical Evidence from India. Global Business Review, 12(1), 159-173.

Smith, J.K. (1987), Trade credit and informational asymmetry, Journal of Finance, Vol. 42 No. 4, pp. 863-872.

Stiglitz, J., Weiss A. (1981), Credit rationing in markets with imperfect information, American Economic Review, 71 (1981), pp. 393-410.

Ukaegbu, B. (2014). The significance of working capital management in determining firm profitability: evidence from developing economies in Africa, Research in International Business and Finance, 31, 1-16.

Wang, Y.J. (2002), Liquidity management, operating performance, and corporate value: evidence from Japan and Taiwan, Journal of Multinational Financial Management, Vol. 12 No. 2, pp. 159-169.

Whited, T.M. (1992). Debt, Liquidity Constraints, and Corporate Investment: Evidence from Panel Data." Journal of Finance 47: 1425-1460.

Wilner, B.S. (2000), The exploitation of relationship in financial distress: the case of trade credit, The Journal of Finance, Vol. 55 No. 1, pp. 153-178.

Zariyawati, M.A., Annuar, M.N., Taufiq, H. and Rahim, A.S.A. (2009), Working capital management and corporate performance: case of Malaysia, Journal of Modern Accounting and Auditing, Vol. 5 No. 11, pp. 47-54. 